\title{
PENGARUH MODEL PEMBELAJARAN BERBASIS MASALAH TERHADAP HASIL BELAJAR FISIKA SISWA SMA
}

\author{
Desti Anggistia*, Eko Suyanto, I Dewa Putu Nyeneng \\ FKIP Universitas Lampung, Jl. Prof. Dr. Soemantri Brojonegoro No. 1 \\ *email: dstianggistia@gmail.com
}

Received: 6 Juni $2018 \quad$ Accepted: 7 Juni $2018 \quad$ Online Published: 8 Juni 2018

\begin{abstract}
The Influence of Problem Based Learning Model on Physics Learning Outcomes of High School Students. The purpose of this study is to determine the effect of problem-based learning model on physics learning outcomes of high school students from cognitive, affective, and psychomotor. The sample of this research is students of class X MIA4 and X MIA 6 SMAN 14 Bandarlampung which is amount 60 students. The research design used is Posttest Control Group Design. Data from the research result is tested using normality test and Independent Sample Ttest. The result of learning of cognitive aspect in experiment class got average score that is 77 higher than control class that is equal to 67, in the affective aspect of experimental class get average value that is equal to 79 higher than control class that is equal to 74 , and at the psychomotor aspect of the experimental class obtained an average score of 79 higher than the control class, that is equal to 71. Based on the result of data analysis, there is a significant influence on the problem-based learning model on physics learning outcomes of high school students from the cognitive, affective, and psychomotor aspect.
\end{abstract}

Keywords: Problem Based Learning, Learning Outcomes, Physics.

\begin{abstract}
Abstrak: Pengaruh Model Pembelajaran Berbasis Masalah terhadap Hasil Belajar Fisika Siswa SMA. Tujuan penelitian ini adalah untuk mengetahui pengaruh dari model pembelajaran berbasis masalah terhadap hasil belajar fisika siswa SMA dari ranah kognitif, afektif,dan psikomotor. Sampel penelitian ini adalah siswa kelas $\mathrm{X}$ MIA 4 dan $\mathrm{X}_{4} \mathrm{MIA}_{6} \mathrm{SMAN}_{14}$ Bandarlampung yang berjumlah 60 siswa. Desain penelitian yang digunakan adalah Posttest Control Group Design. Data hasil uji penelitian diuji dengan analisis uji normalitas dan Independent Sample T-test. Hasil belajar ranah kognitif pada kelas eksperimen memperoleh nilai rata-rata yaitu sebesar 77 lebih tinggi dibandingkan dengan kelas kontrol yaitu sebesar 67, pada ranah afektif kelas eksperimen memperoleh nilai rata-rata yaitu sebesar 79 lebih tinggi dibandingkan dengan kelas kontrol yaitu sebesar 74, dan pada ranah psikomotor kelas eksperimen memperoleh nilai rata-rata yaitu sebesar 79 lebih tinggi dibandingkan dengan kelas kontrol yaitu 71. Berdasarkan hasil analisis data, terdapat pengaruh yang signifikan pada model pembelajaran berbasis masalah terhadap hasil belajar fisika siswa SMA dari ranah kognitif, afektif, dan psikomotor.
\end{abstract}

Kata Kunci: Pembelajaran Berbasis Masalah, Hasil Belajar, Fisika. 


\section{PENDAHULUAN}

Salah satu masalah yang dihadapi dalam dunia pendidikan di Indonesia adalah lemahnya proses pembelajaran (Dewi, 2015). Proses pembelajaran masih didominasi oleh guru, dimana siswa hanya menerima materi, mencatat, dan mengerjakan soal. Pembelajaran yang didominasi oleh guru menyebabkan siswa pasif tanpa melibatkan siswa dalam proses pembelajaran untuk belajar mengembangkan logika dan cara berfikir sehingga minat belajar siswa kurang yang menyebabkan hasil belajar cenderung rendah.

Hasil wawancara terhadap seorang guru Fisika kelas X di SMA Negeri 14 Bandarlampung, proses pembelajaran masih berpusat pada guru. Guru lebih banyak memberikan materi dengan ceramah dan penugasan kepada siswa, tanpa melibatkan siswa dalam proses pembelajaran sehingga siswa sulit memahami konsep materi fisika yang diberikan oleh guru, dan mengakibatkan hasil belajar siswa sebagian besar belum mencapai nilai Kriteria Kelulusan Minimal (KKM), yaitu 73.

Proses pembelajaran dengan kondisi yang diharapkan, yaitu fokus pembelajaran berpusat pada siswa. Guru harus menciptakan kondisi belajar dimana siswa terlibat aktif dalam kegiatan pembelajaran, sehingga mereka dapat berusaha memahami konsep materi, dan meningkatkan keterampilan berfikir.

Kesenjangan yang terjadi antara kondisi yang ditemui di sekolah dengan kondisi yang diharapkan dapat disebabkan oleh model pembelajaran yang digunakan guru membatasi keterlibatan siswa untuk aktif mengembangkan potensinya. Pembelajaran yang berpusat pada guru menyebabkan siswa tidak terlibat aktif dalam proses pem- belajaran. Hal ini membuat siswa kehilangan minat untuk belajar fisika dan sulit memahami materi dengan baik, sehingga mengakibatkan hasil belajar cenderung rendah. Oleh karena itu, diperlukannya model pembelajaran yang dapat membuat kondisi aktif dalam proses pembelajaran.

Salah satu model pembelajaran yang dapat memberikan kondisi belajar aktif kepada siswa, yaitu pembelajaran berbasis masalah. Pembelajaran berbasis masalah adalah pembelajaran yang melalui tahaptahap metode ilmiahnya siswa dapat memecahkan suatu masalah berdasarkan pengalaman nyata yang di alami sendiri dalam kehidupan seharihari (Ngalimun, dkk., 2016: 117-118). Pemecahan masalah berdasarkan pengalaman nyata pada kehidupan sehari-hari, akan memudahkan siswa dalam menyusun pengetahuan dan menemukan kaitan terhadap materi pelajaran dan mengingat materi yang dipelajari (Purnamaningrum, 2012).

Sebuah masalah yang diberikan dalam pembelajaran berbasis masalah harus dapat membangkitkan pengetahuan siswa. Siswa dapat mengeluarkan seluruh pengetahuan yang dimiliki guna menyelesaikan masalah, dan dapat meningkatkan aktivitas pembelajaran siswa. Melalui pemecahan masalah dapat memperlihatkan kepada siswa bahwa setiap mata pelajaran, pada dasarnya merupakan cara berpikir, dan sesuatu yang harus dimengerti oleh siswa, bukan hanya sekedar belajar dari guru atau buku-buku saja (Sanjaya, 2006: 221).

Hasil belajar merupakan perubahan tingkah laku pada peserta didik akibat belajar. Hasil tidak akan pernah dihasilkan selama orang tidak melakukan sesuatu. Untuk meng- 
hasilkan sebuah prestasi dibutuhkan keuletan, sungguh-sungguh, kemauan yang tinggi dan rasa optimisme dirilah yang mampu untuk mencapainya. Hal ini juga dikemukakan oleh Rahayu (2015) bahwa hasil belajar ditingkatkan melalui usaha sadar yang dilakukan secara sistematis mengarah kepada perubahan yang positif.

Pembelajaran berbasis masalah selain meningkatkan pengetahuan kognitif, juga dapat meningkatkan afektif dan psikomotor siswa. Hal tersebut didukung oleh penelitian dari Perdana (2017) mengemukakan bahwa rata-rata nilai sebelum diterapkan pembelajaran berbasis masalah hanya sebesar 23,40 dan setelah diterapkan rata-rata hasil belajar fisika meningkat menjadi 65,69. Terjadi peningkatan rata-rata hasil belajar fisika siswa sebesar 42,29 setelah diterapkan pembelajaran berbasis masalah. Simatupang dan Simatupang (2015) menambahkan bahwa sebelum diberikan perlakuan dengan pembelajaran berbasis masalah nilai rata-rata pretes pada kelas eksperimen adalah 3,190 dan kelas kontrol adalah 4,575. Kemudian setelah diberi perlakuan dengan pembelajaran berbasis masalah pada kelas eksperimen, maka nilai rata-rata postes sebesar 6,138 dan kelas kontrol diberikan pembelajaran konvensional nilai ratarata postesnya, yaitu 5,488. Hasil belajar siswa mengalami peningkatan pada kelas eksperimen sebesar 2,948 dan pada kelas kontrol sebesar 0,913. Demikian juga aktivitas siswa pada kelas eksperimen mengalami peningkatan, yaitu pada pertemuan I rata-rata aktivitas siswa kelas eksperimen 73,985, pada pertemuan II rata-rata adalah 80,160 sedangkan pada pertemuan III meningkat menjadi 81,410. Dan rata-rata keseluruhan nilai aktivitas siswa selama pembelajaran berbasis masalah adalah 78,52. Dengan demikian, pembelajaran berbasis masalah sangat berpengaruh untuk membantu siswa dalam meningkatkan hasil belajar, karena siswa lebih aktif dalam pembelajaran dengan masalah (Dalem, 2017).

Adapun tujuan dari penelitian ini adalah untuk mengetahui pengaruh dari model pembelajaran berbasis masalah terhadap hasil belajar fisika siswa SMA dari ranah kognitif, afektif, dan psikomotor. Berdasarkan pemaparan masalah di atas, maka dilakukanlah penelitian yang berjudul "Pengaruh Model Pembelajaran Berbasis Masalah terhadap Hasil Belajar Fisika Siswa SMA".

\section{METODE}

Penelitian ini merupakan penelitian eksperimen dengan desain penelitian menggunakan Posttest Control Group Design. Desain penelitian dapat dilihat pada Tabel 1.

Tabel 1. Desain Penelitian

\begin{tabular}{cccc}
\hline Materi & Kelas A & Kelas B & Postes \\
\hline 1 & $\mathrm{X}_{1}$ & $\mathrm{X}_{2}$ & $\mathrm{O}_{1}$ \\
2 & $\mathrm{X}_{2}$ & $\mathrm{X}_{1}$ & $\mathrm{O}_{2}$ \\
3 & $\mathrm{X}_{1}$ & $\mathrm{X}_{2}$ & $\mathrm{O}_{3}$ \\
4 & $\mathrm{X}_{2}$ & $\mathrm{X}_{1}$ & $\mathrm{O}_{4}$ \\
\hline
\end{tabular}

Desain penelitian menggunakan dua kelas, yaitu kelas eksperimen dan kelas kontrol yang masing-masing kelas pada tiap materi diberi perlakuan yang berbeda. Perlakuan yang diberikan pada kelas eksperimen, yaitu model pembelajaran berbasis masalah $\left(\mathrm{X}_{1}\right)$ dan pada kelas kontrol, yaitu model pembelajaran konvensional $\left(\mathrm{X}_{2}\right)$.

Populasi penelitian ini, yaitu seluruh siswa kelas $X$ MIA SMA Negeri 14 Bandarlampung pada semester genap tahun ajaran 2017/ 2018 dengan jumlah 192 siswa yang terbagi dalam 6 kelas. Sedangkan, 
sampel penelitian yang diambil, yaitu kelas $\mathrm{X} \quad \mathrm{MIA}_{4}$ dan $\mathrm{X} \quad \mathrm{MIA}_{6}$ yang berjumlah 60 siswa. Sampel penelitian dilakukan dengan teknik random sampling, yaitu dengan cara diundi.

Variabel dalam penelitian ini, yaitu variabel bebas adalah model pembelajaran berbasis masalah (X) dan variabel terikatnya adalah hasil belajar (Y).

Selama proses pembelajaran berlangsung, guru melakukan pengamatan dan menilai sikap (afektif), serta keterampilan (psikomotor) siswa menggunakan lembar observasi. Kemudian pada akhir pembelajaran diberikan postes yang pada tiap pertemuaannya adalah 10 soal. Instrumen untuk soal postes diuji validitas dan reliabilitas terlebih dahulu, kemudian setelah valid dan reliabel instrumen dapat digunakan untuk soal postes.

Data yang diperoleh pada penelitian ini, yaitu hasil belajar pada ranah kognitif, afektif, dan psikomotor. Setelah data diperoleh, maka dilakukan uji analisis data berupa uji normalitas menggunakan uji Saphiro-Wilk pada IBM SPSS 21 dan uji hipotesis, yaitu uji independent sample t-test untuk mengetahui apakah hipotesis dapat diterima atau ditolak.

\section{HASIL DAN PEMBAHASAN}

Penelitian yang dilakukan bertujuan untuk melihat apakah proses pembelajaran yang berpusat pada siswa dengan menggunakan model pembelajaran berbasis masalah berpengaruh terhadap hasil belajar siswa dari ranah kognitif, afektif, dan psikomotor pada materi Dinamika dan Hukum Newton.

Penelitian ini dilakukan pada kelas X SMA Negeri 14 Bandarlampung, yaitu kelas $\mathrm{X} \mathrm{MIA}_{4}$ dan $\mathrm{X}$ MIA $_{6}$. Masing-masing kelas terdiri dari 30 siswa. Proses pembelajaran di- lakukan sebanyak empat pertemuan.

Sebelum melakukan penelitian, soal terlebih dahulu diujicoba pada siswa kelas XI yang berjumlah 32 siswa yang telah belajar mengenai Dinamika dan Hukum Newton dengan jumlah soal sebanyak 44 soal. Setelah itu, dilakukan uji validitas dan reliabilitas. Jumlah soal yang dinyatakan valid, yaitu 40 soal.

Pada penelitian ini, data kuantitatif yang diperoleh, yaitu terdiri dari penilaian kognitif, afektif, dan psikomotor siswa. Penilaian kognitif diperoleh berdasarkan hasil postes yang dilakukan pada tiap akhir tatap muka pembelajaran selama 4 kali. Tiap pertemuan, siswa mengerjakan postes dengan jumlah 10 soal pilihan ganda. Penilaian afektif dan psikomotor dinilai dengan menggunakan lembar pengamatan selama proses pembelajaran berlangsung.

Tabel 2 menunjukkan rata-rata hasil belajar ranah kognitif pada kelas eksperimen lebih besar dari kelas kontrol. Rata-rata hasil belajar pada kelas eksperimen adalah 77, termasuk dalam kategori sangat baik. Sedangkan, rata-rata hasil belajar kelas kontrol adalah 67, termasuk dalam kategori baik.

Tabel 3 menunjukkan rata-rata hasil belajar ranah afektif kelas eksperimen lebih besar dari kelas kontrol. Pada kelas eksperimen ratarata hasil belajarnya adalah 79 , dalam kategori sangat baik. Sedangkan, ratarata kelas kontrol adalah 74 , dalam kategori baik.

Tabel 4 menunjukkan rata-rata hasil belajar ranah psikomotor kelas eksperimen lebih besar dari kelas kontrol. Pada kelas eksperimen ratarata hasil belajarnya adalah 78 , dalam kategori sangat baik. Sedangkan, ratarata kelas kontrol adalah 71 , dalam kategori baik. 
Tabel 2. Data Hasil Belajar Siswa Ranah Kognitif

\begin{tabular}{cccc} 
No. & Parameter & Kelas Eksperimen & Kelas Kontrol \\
\hline 1 & Jumlah siswa & 30 & 30 \\
2 & Nilai terendah & 50 & 40 \\
3 & Nilai tertinggi & 100 & 90 \\
4 & Rata-rata nilai & 77 & 67 \\
\hline
\end{tabular}

Tabel 3. Data Hasil Belajar Siswa Ranah Afektif

\begin{tabular}{cccc}
\hline No. & Parameter & Kelas Eksperimen & Kelas Kontrol \\
\hline 1 & Jumlah siswa & 30 & 30 \\
2 & Rata-rata nilai pertemuan ke-1 & 77 & 71 \\
3 & Rata-rata nilai pertemuan ke-2 & 77 & 72 \\
4 & Rata-rata nilai pertemuan ke-3 & 80 & 75 \\
5 & Rata-rata nilai pertemuan ke-4 & 83 & 78 \\
6 & Rata-rata nilai seluruhnya & 79 & 74 \\
\hline
\end{tabular}

Tabel 4. Data Hasil Belajar Siswa Ranah Psikomotor

\begin{tabular}{cccc}
\hline No. & Parameter & Kelas Eksperimen & Kelas Kontrol \\
\hline 1 & Jumlah siswa & 30 & 30 \\
2 & Rata-rata nilai pertemuan ke-1 & 73 & 67 \\
3 & Rata-rata nilai pertemuan ke-2 & 78 & 69 \\
4 & Rata-rata nilai pertemuan ke-3 & 78 & 74 \\
5 & Rata-rata nilai pertemuan ke-4 & 83 & 74 \\
6 & Rata-rata nilai seluruhnya & 78 & 71 \\
\hline
\end{tabular}

Pengukuran selanjutnya, yaitu normalitas untuk mengetahui data yang diperoleh normal atau tidak. Data dikatakan berdistribusi normal apabila nilai signifikansi > 0.050, sedangkan data yang tidak berdistribusi normal yaitu apabila nilai signifikansi $<0.050$.

Berdasarkan data yang didapatkan, hasil belajar pada ranah kognitif kelas kontrol dan eksperimen memiliki nilai signifikansi > 0,050. Data hasil belajar pada ranah afektif kelas kontrol dan eksperimen memiliki nilai signifikansi $>0,050$. Data hasil belajar pada ranah psikomotor kelas kontrol dan eksperimen memiliki nilai signifikansi $>0,050$. Hal ini menyatakan bahwa hasil belajar ranah kognitif, afektif, dan psikomotor berdistribusi normal.

Setelah didapatkan data yang telah berdistribusi secara normal, maka dilakukan pengujian hipotesis dengan uji independent sample t-test. 
Tabel 5. Hasil Uji Independent Sample T-test Ranah Kognitif

\begin{tabular}{lccc}
\hline & & \multicolumn{2}{c}{ Nilai } \\
& & $\begin{array}{c}\text { Equal Variances } \\
\text { Assumed }\end{array}$ & $\begin{array}{l}\text { Equal Variances } \\
\text { Not Assumed }\end{array}$ \\
\hline $\begin{array}{l}\text { Levene's Test For } \\
\text { Equality Of Variances }\end{array}$ & $\mathrm{F}$ & 1,314 & \\
t-test for equality & $\mathrm{Sig}$ & 0,256 & 8,574 \\
of Means & $\mathrm{t}$ & 8,574 & 54,955 \\
& $\mathrm{Df}$ & 58 & 0,000 \\
\hline
\end{tabular}

Tabel 6. Hasil Uji Independent Sample T-test Ranah Afektif

\begin{tabular}{lccc}
\hline & & \multicolumn{2}{c}{ Nilai } \\
& & Equal Variances & $\begin{array}{l}\text { Equal Variances } \\
\text { Assumed }\end{array}$ \\
Levene's Test For & $\mathrm{F}$ & 1,404 & \\
Equality Of Variances & $\mathrm{Sig}$ & 0,241 & \\
t-test for equality & $\mathrm{t}$ & 3,799 & 3,799 \\
of Means & $\mathrm{Df}$ & 58 & 51,929 \\
& Sig (2-tailed) & 0,000 & 0,000 \\
\hline
\end{tabular}

Tabel 7. Hasil Uji Independent Sample T-test Ranah Psikomotor

\begin{tabular}{lccc}
\hline & & \multicolumn{2}{c}{ Nilai } \\
& & $\begin{array}{c}\text { Equal Variances } \\
\text { Assumed }\end{array}$ & $\begin{array}{l}\text { Equal Variances } \\
\text { Not Assumed }\end{array}$ \\
\hline $\begin{array}{l}\text { Levene's Test For } \\
\text { Equality Of Variances }\end{array}$ & $\mathrm{F}$ & 4,488 & \\
t-test for equality & $\mathrm{Sig}$ & 0,380 & \\
of Means & $\mathrm{t}$ & 4,232 & 4,232 \\
& $\mathrm{Df}$ & 58 & 51,722 \\
& Sig (2-tailed) & 0,000 & 0,000 \\
\hline
\end{tabular}

Tabel 5 menunjukkan nilai $t_{\text {hitung }}$ Equal Varian Assumed sebesar 8,574 dengan $t_{\text {tabel }}$ sebesar 2,000. Sehingga nilai $t_{\text {hitung }}>t_{\text {tabel }}(8,574>2,000)$ dan signifikansi yang diperoleh $0,000<$ 0,050 , yang dapat diambil kesimpulan bahwa $\mathrm{H}_{0}$ ditolak. Artinya, terdapat perbedaan yang signifikan terhadap rata-rata hasil belajar ranah kognitif pada kelas eksperimen dan kelas kontrol, dimana hasil belajar Fisika siswa ranah kognitif lebih tinggi setelah menggunakan model pembelajaran berbasis masalah daripada menggunakan model pembelajaran konvensional.

Tabel 6 menunjukkan nilai $t_{\text {hitung }}$ Equal Varian Assumed sebesar 3,799 dengan $t_{\text {tabel }}$ sebesar 2,000. Sehingga nilai $t_{\text {hitung }}>t_{\text {tabel }}(3,799>2,000)$ dan signifikansi yang diperoleh 0,000 $<0,050$, yang dapat diambil 
kesimpulan bahwa $\mathrm{H}_{0}$ ditolak. Artinya, terdapat perbedaan yang signifikan terhadap rata-rata hasil belajar ranah afektif pada kelas eksperimen dan kelas kontrol, dimana hasil belajar Fisika siswa ranah afektif lebih tinggi setelah meng-gunakan model pembelajaran berbasis masalah daripada menggunakan model pembelajaran konvensional.

Tabel 7 menunjukkan nilai $t_{\text {hitung }}$ Equal Varian Assumed sebesar 4,232 dengan $t_{\text {tabel }}$ sebesar 2,000. Sehingga nilai $t_{\text {hitung }}>t_{\text {tabel }}(4,232>2,000)$ dan signifikansi yang diperoleh $0,000<$ 0,050 , yang dapat diambil kesimpulan bahwa $\mathrm{H}_{0}$ ditolak. Artinya, terdapat perbedaan yang signifikan terhadap rata-rata hasil belajar ranah psikomotor pada kelas eksperimen dan kelas kontrol, dimana hasil belajar Fisika siswa ranah kognitif lebih tinggi setelah menggunakan model pembelajaran berbasis masalah daripada menggunakan model pembelajaran konvensional.

Nilai rata-rata hasil belajar siswa ranah kognitif didapat dari nilai postes siswa setelah diberikan perlakuan pembelajaran dengan model pembelajaran berbasis masalah (eksperimen) dan model pembelajaran konvensional. Gambar 1 menunjukkan hasil belajar siswa ranah kognitif pada kelompok kontrol dengan perlakuan model pembelajaran konvensional memperoleh nilai rata-rata postes, yaitu 67 lebih rendah dibanding kelompok eksperimen dengan perlakuan model pembelajaran berbasis masalah yang rata-rata nilainya 77 .

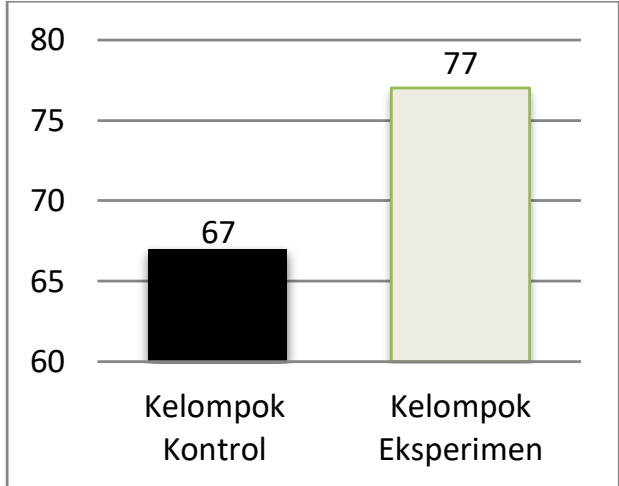

Gambar 1. Rata-Rata Hasil Belajar Siswa Ranah Kognitif

Pada hasil belajar ranah afektif, pertemuan pertama guru melihat keantusiasan siswa dalam diskusi kelompok. Dalam diskusi kelompok, guru sudah menyediakan lembar pengamatan. Guru mengamati kegiatan siswa dalam diskusi kelompok. Pada pertemuan kedua, ketiga, dan ke-empat, siswa melakukan percobaan dan guru menilai keantusiasan siswa dalam melaksanakan percobaan dengan lembar pengamatan. Pada kelas eksperimen, siswa lebih antusias dalam melakukan percobaan dikarenakan, model pembelajaran berbasis masalah berpusat pada siswa, jadi menekankan siswa untuk lebih aktif dalam melakukan percobaan dan menemukan jawaban dari sebuah permasalahan yang berkaitan dengan materi pembelajaran. Sedangkan, kelas kontrol menggunakan model pembelajaran konvensional yang berpusat pada guru, jadi guru menggunakan metode ceramah sedangkan siswa hanya mendengarkan dan mencatat apa yang disampaikan oleh guru. Keantusiasan siswa dapat dilihat dalam perolehan nilai rata-rata hasil belajar siswa ranah afektif pada Gambar 2.

Gambar 3 menunjukkan hasil belajar siswa ranah afektif pada kelas kontrol dengan perlakuan model pembelajaran konvensional memperoleh 
nilai rata-rata afektif, yaitu 74 lebih rendah dibanding kelompok eksperimen dengan perlakuan model pembelajaran berbasis masalah yang ratarata nilainya 79 .

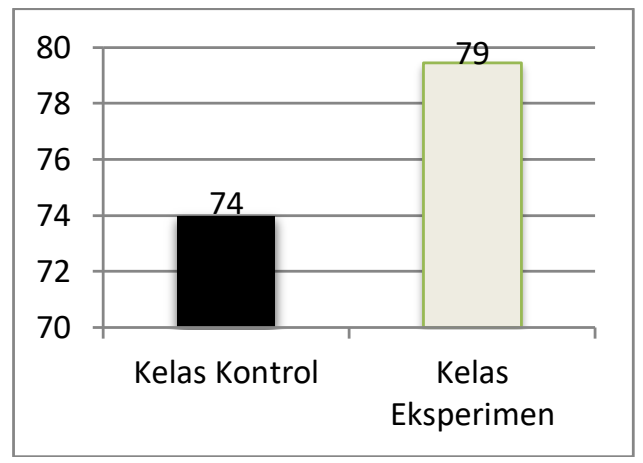

Gambar 2. Rata-Rata Hasil Belajar

Siswa Ranah Afektif

Pada hasil belajar siswa ranah psikomotor, didapatkan nilai rata-rata kelas eksperimen sebesar 78 dan kelas kontrol 71. Hal ini dapat dilihat pada Tabel 4. Pada pertemuan pertama, guru mengamati siswa dalam diskusi kelompok. Guru fokus dengan kemampuan keterampilan komunikasi siswa, penyampaian pendapat, kerjasama kelompok dan tanggungjawab pada laporan. Sedangkan pertemuan kedua, ketiga, dan keempat diisi dengan praktikum. Pada saat siswa melakukan praktikum, guru menilai siswa dalam keterampilan menyiapkan alat dan bahan, melakukan percobaan, menganalisis data, merapikan alat dan bahan, dan mempresentasikan hasil praktik.

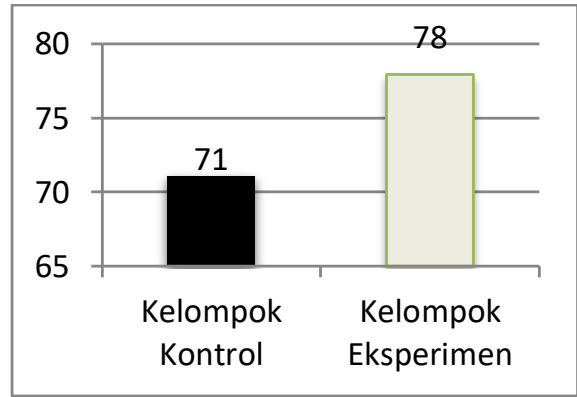

Gambar 3. Rata-Rata Hasil Belajar Siswa Ranah Psikomotor
Hasil penelitian menunjukkan adanya pengaruh model pembelajaran berbasis masalah terhadap hasil belajar fisika siswa SMA dari segi kognitif, afektif, dan psikomotor pada materi Dinamika dan Hukum Newton. Hal ini ditunjukkan dengan adanya perbedaan hasil belajar pada kelas eksperimen dengan kelas kontrol, yaitu pada kelas eksperimen rata-rata nilai hasil belajar ranah kognitif yang didapat dari hasil postes adalah 77 , sedangkan kelas kontrol adalah 67. Demikian pula pada ranah afektif, kelas eksperimen mengalami peningkatan, yaitu pada pertemuan I ratarata nilainya adalah 77 , pertemuan II adalah 77 , pertemuan III meningkat menjadi 80, dan pertemuan IV meningkat kembali menjadi 83, serta rata-rata nilai akhir afektif nya adalah 79 dengan kategori sangat baik. Pada kelas kontrol juga mengalami peningkatan pada ranah afektif, yaitu pertemuan I adalah 71 , pertemuan II meningkat menjadI 72 , pertemuan III meningkat menjadi 75 , pertemuan IV meningkat kembali menjadi 78 , dan rata-rata nilai akhir afektifnya adalah 74 dengan kategori baik.

Selain itu, hasil belajar pada ranah psikomotor mengalami peningkatan juga. Pada kelas eksperimen rata-rata nilai pertemuan I adalah 73 , pertemuan II meningkat menjadi 78 , pertemuan III 78 , dan pertemuan IV meningkat menjadi 83 , serta rata-rata nilai akhir psikomotor adalah 78 kategori sangat baik. Pada kelas kontrol rata-rata nilai pertemuan I adalah 67, pertemuan II meningkat menjadi 69, pertemuan III meningkat menjadi 74, dan pertemuan IV adalah 74 , serta rata-rata nilai akhir psikomotor adalah 71 kategori baik.

Pada penelitian Perdana (2017) menyatakan bahwa terdapat perbedaan hasil belajar siswa meng- 
gunakan pembelajaran berbasis masalah sebagai kelas eksperimen dan pembelajaran konvensional sebagai kelas kontrol, dengan rata-rata nilai nilai $N$-gain pada kelas eksperimen adalah 0,570 dan kelas kontrol adalah 0,298 . Artinya, terjadi peningkatan yang lebih besar jika dilihat dari perbedaan rata-rata $N$-gain hasil belajar fisika kelas eksperimen dan kelas kontrol. Penelitian Maharani (2016) menyatakan bahwa terdapat perbedaan hasil belajar siswa menggunakan pembelajaran berbasis masalah sebagai kelas eksperimen dan pembelajaran konvensional sebagai kelas kontrol, dengan nilai $N$-gain pada kelas eksperimen adalah 0,71 lebih tinggi dibandingkan dengan nilai $\mathrm{N}$-gain kelas control, yaitu 0,55 , sehingga dikatakan ada pengaruh terhadap hasil belajar siswa. Penelitian Khairuddin (2012) menyatakan bahwa hasil belajar yang menggunakan pembelajaran berbasis masalah lebih tinggi dengan rata-rata nilai postes 66 , daripada hasil belajar yang menggunakan pembelajaran konvensional dengan rata-rata nilai postes 56. Oleh karena itu, dengan menggunakan model pembelajaran berbasis masalah dapat memberikan pengaruh yang lebih baik dibandingkan dengan model pembelajaran konvensional, karena dapat meningkatkan kemampuan dan aktivitas siswa untuk lebih aktif.

\section{KESIMPULAN DAN SARAN \\ Kesimpulan}

Berdasarkan hasil data dan pembahasan, dapat disimpulkan sebagai berikut: 1) ada pengaruh model pembelajaran berbasis masalah terhadap hasil belajar siswa pada ranah kognitif, dibuktikan dengan adanya perbedaan nilai rata-rata hasil postes siswa pada kelas eksperimen, yaitu 77 lebih tinggi dibandingkan dengan kelas kontrol, yaitu 67 dan berdasarkan uji independent sample t-test nilai signifikansi $0,000<0,050$, maka $\mathrm{H}_{0}$ ditolak; 2) ada pengaruh model pembelajaran berbasis masalah terhadap hasil belajar siswa pada ranah afektif, dibuktikan dengan adanya perbedaan nilai rata-rata afektif siswa pada kelas eksperimen, yaitu 79 lebih tinggi dibandingkan dengan kelas kontrol, yaitu 74 dan berdasarkan uji independent sample $t$ test nilai signifikansi $0,000<0,050$, maka $\mathrm{H}_{0}$ ditolak; 3) ada pengaruh model pembelajaran berbasis masalah terhadap hasil belajar siswa pada ranah psikomotor, dibuktikan dengan adanya perbedaan nilai rata-rata pada kelas eksperimen, yaitu 78 lebih tinggi dibandingkan dengan kelas kontrol, yaitu 71 dan berdasarkan uji independent sample t-test nilai signifikansi $0,000<0,050$, maka $\mathrm{H}_{0}$ ditolak.

\section{Saran}

Berdasarkan hasil penelitian yang telah dilakukan, peneliti memberi saran, yaitu model pembelajaran berbasis masalah dapat dijadikan salah satu alternatif bagi guru di sekolah dalam meningkatkan hasil belajar siswa pada ranah kognitif, afektif, dan psikomotor. 
DAFTAR RUJUKAN

Dalem, I Putu Agastya. 2017. Pengaruh Pembelajaran Berbasis Masalah Terhadap Hasil Belajar Materi Hukum Newton Tentang Gerak. Jurnal Pembelajaran Fisika. 5 (3): 10-11.

Dewi, Sri. 2015. The Effect Of Student Metacognition Ability To Their Reasoning By Using Realistic Mathematical Education Approach At Secondary School Of Sakti Jambi. Jurnal Ilmiah Universitas Batanghari Jambi. 15 (3): 171.

Khairuddin. 2012. Pengaruh Model Problem Based Learning (Belajar Berdasarkan Masalah) terhadap Hasil Belajar Kognitif Siswa SMAN 1 Ngaglik pada Pembelajaran Fisika Untuk Materi Listrik Dinamis. Jurnal Pendidikan Fisika. 1 (3).

Maharani, Lucia Dewanti. 2016. Penerapan Model Pembelajaran Berbasis Masalah Untuk Menumbuhkan Kemampuan Berpikir Kritis Siswa. Jurnal Pembelajaran Fisika. 4 (3): 149.

Ngalimun, Muhammad Fauzani dan Ahmad Salabi. 2016. Strategi dan Model Pembelajaran. Yogyakarta: Aswaja Pressindo.
Perdana, Fadel Rista. 2017. Pengaruh Pembelajaran Menggunakan Lembar Kerja Siswa Berbasis Problem Based Learning pada Materi Fluida Statis terhadap Hasil Belajar Fisika. Jurnal Pendidikan Fisika. 5 (4): 48.

Purnamaningrum, Arifah. 2012. Peningkatan Kemampuan Berpikir Kreatif melalui Problem Based Learning (PBL) pada Pembelajaran Biologi Siswa Kelas X-10 SMA Negeri 3 Surakarta Tahun Pelajaran 2011/2012. Jurnal Pendidikan Biologi. 4 (3): 3-4.

Rahayu, Puspita Indah. 2015. Perbandingan Hasil Belajar Siswa antara Pembelajaran Menggunakan PBL dan Discovery Learning. Jurnal Pembelajaran Fisika. 3 (5): 2.

Sanjaya, Wina. 2006. Strategi Pembelajaran Berorientasi Standar Proses Pendidikan. Jakarta: Kencana Group.

Simatupang, Mardiana Afriany dan Sehat Simatupang. 2015. Pengaruh Model Problem Based Learning Berbantuan Peta Konsep terhadap Hasil Belajar Siswa SMA. Jurnal Inpafi. 3 (1): 128 . 